\title{
Climate change scenarios applied to viticultural zoning in Europe
}

\author{
Aureliano C. Malheiro ${ }^{1,2, *}$, João A. Santos ${ }^{1}$, Helder Fraga ${ }^{1}$, Joaquim G. Pinto ${ }^{3}$ \\ ${ }^{1}$ Centre for Research and Technology of Agro-Environment and Biological Sciences (CITAB), \\ University of Trás-os-Montes e Alto Douro, 5001-801 Vila Real, Portugal \\ ${ }^{2}$ Departamento de Agronomia, Universidade de Trás-os-Montes e Alto Douro, PO Box 1013, 5001-801 Vila Real, Portugal \\ ${ }^{3}$ Institute for Geophysics and Meteorology, University of Cologne, 50923 Cologne, Germany
}

\begin{abstract}
Climate is one of the main factors controlling winegrape production. Bioclimatic indices describing the suitability of a particular region for wine production are a widely used zoning tool. Seven suitable bioclimatic indices characterize regions in Europe with different viticultural suitability, and their possible geographical shifts under future climate conditions are addressed using regional climate model simulations. The indices are calculated from climatic variables (daily values of temperature and precipitation) obtained from transient ensemble simulations with the regional model COSMO-CLM. Index maps for recent decades (1960-2000) and for the 21st century (following the IPCC-SRES B1 and A1B scenarios) are compared. Results show that climate change is projected to have a significant effect on European viticultural geography. Detrimental impacts on winegrowing are predicted in southern Europe, mainly due to increased dryness and cumulative thermal effects during the growing season. These changes represent an important constraint to grapevine growth and development, making adaptation strategies crucial, such as changing varieties or introducing water supply by irrigation. Conversely, in western and central Europe, projected future changes will benefit not only wine quality, but might also demarcate new potential areas for viticulture, despite some likely threats associated with diseases. Regardless of the inherent uncertainties, this approach provides valuable information for implementing proper and diverse adaptation measures in different European regions.
\end{abstract}

KEY WORDS: Vitis vinifera L. - Viticultural zoning $\cdot$ Bioclimatic indices $\cdot$ Regional climate change · Europe $\cdot$ COSMO-CLM

Resale or republication not permitted without written consent of the publisher

\section{INTRODUCTION}

Winemaking has a predominant economic, social and environmental relevance in Europe, which is responsible for approximately $70 \%$ of the global production volume (mainly in Italy, France and Spain) and about $60 \%$ of Vitis vinifera L. area under cultivation worldwide (OIV 2006, www.oiv.int). Studies addressing the influence of climate variability and change in viticulture are particularly pertinent, as climate is the leading factor for grapevine yield and quality (van Leeuwen et al. 2004, Santos et al. 2010) and for grapevine global geographical distribution (Jones 2006). In effect, grapevines have very specific climatic require- ments: they are a heat-demanding crop, needing proper high radiation intensities and temperatures, not only during their vegetative growth and development, but also for berry ripening, since they are also highly sensitive to late frost occurrences (e.g. Spellman 1999, Magalhães 2008).

Even though this crop may tolerate extreme temperatures of about 15 to $20^{\circ} \mathrm{C}$ below zero for short time periods during winter, values lower than $-1^{\circ} \mathrm{C}$ in spring may damage developing buds and young leaves and shoots (Hidalgo 2002). Nevertheless, cold temperatures in winter (chilling) are important for breaking bud dormancy (Kliewer \& Soleimani 1972) and promoting the storage of carbohydrate reserves in 
perennial organs (roots, trunk and canes) for following-year growth (Bates et al. 2002, Field et al. 2009). A $10^{\circ} \mathrm{C}$ base temperature is the minimum threshold considered necessary for grapevines to initiate their growing cycle (Amerine \& Winkler 1944, Winkler et al. 1974). Conversely, extreme heat (e.g. temperatures above 40 to $45^{\circ} \mathrm{C}$ ) may irreversibly impair some physiological processes (Berry \& Björkman 1980), thus leading to poor grape yields and quality (Kliewer 1977, Mullins et al. 1992). Furthermore, annual precipitation and its seasonal distribution are also critical. High soil moisture is needed during budburst and shoot and inflorescence development, followed by dry and stable atmospheric conditions from flowering to berry ripening (Jones \& Davis 2000, Nemani et al. 2001, Jones et al. 2005a, Ramos et al. 2008). Due to these selective climatic needs, most wine-producing areas are geographically located within the latitude range of 30 to $50^{\circ}$ over the northern hemisphere (e.g. Spellman 1999, Hidalgo 2002), where the warm temperate climates (Kottek et al. 2006), including the Mediterranean type, are typically found. These climates roughly correspond to the belt limited by the 10 to $20^{\circ} \mathrm{C}$ annual mean isotherms (Spellman 1999) or, as more recently defined, to the 12 to $22^{\circ} \mathrm{C}$ growing season mean isotherms (Jones 2006). Moreover, climate is a critical component of the terroir concept (homogeneous winegrowing region in terms of climate, soil, agronomical and oenological practices, and social traditions) (Vaudour 2002, Vaudour \& Shaw 2005).

Winegrapes are likely to face new challenges in the coming decades due to climate change. Shifts in grapevine phenology, disease and pest patterns, yield and ripening potential, and wine styles are projected to take place in response to future conditions (Kenny \& Harrison 1992, Schultz 2000, Jones et al. 2005b). An above average warming is predicted for Europe, particularly in winter over eastern areas and in summer over southwestern areas, where a temperature increase between 2.2 and $5.1^{\circ} \mathrm{C}$ is expected to occur during the 21st century (cf. Meehl et al. 2007; results for the IPCC Special Report on Emission Scenarios, SRES, B1 and A1B scenarios). Furthermore, mean annual precipitation is projected to diminish in most of southern Europe (4 to $27 \%$ ) and to increase in most of its northern regions (Meehl et al. 2007). In fact, the recently recorded climatic trends are in line with future projections. As an illustration, Jones et al. (2005b) analysed most of the world's high-quality wine-producing regions and concluded that the growing season mean temperatures have risen about $1.26^{\circ} \mathrm{C}$ over the past 50 yr (1950-1999). Hence, some regions (e.g. in southern Europe) may already be at the limit of ideal conditions for high-quality wine production (Kenny \& Harrison 1992, Jones et al. 2005b). Conversely, changing climatic conditions have already allowed some of the northern regions (e.g. southern England) to become more adequate for viticulture. As such, climate change may have both positive and negative impacts on viticulture and has the potential to cause significant geographical displacements in traditional growing areas (Jones et al. 2005b).

Taking into account the interactions between winegrape climatic requirements and its growing cycle, several climate-based (bioclimatic) indices have been proposed to describe the suitability of different winegrowing areas. One of the earliest indices was the heat unit concept, using a growing degree base of $10^{\circ} \mathrm{C}$ (degree-days), since grapevines need a specific heat accumulation to complete their phenological stages (Amerine \& Winkler 1944). The Cool Night Index $\left(\mathrm{CI}_{;}\right.$ Tonietto 1999, Tonietto \& Carbonneau 2004), which accounts for minimum temperatures during maturation, and the diurnal temperature range (Gladstones 1992, Ramos et al. 2008) are other strictly thermal indices. High daily temperature ranges with relatively cool nights during ripening tend to be beneficial for the production of high-quality wines, for example by synthesizing anthocyanins in grapes (Kliewer \& Torres 1972, Fregoni 2003). However, it should be noted that the effect of night temperature on physiological ripening may be day-temperature and grape-variety dependent (Kliewer \& Torres 1972).

Additionally, the Hydrothermic Index of Branas, Bernon and Levadoux (HyI; Branas et al. 1946) evaluates the potential risk of grapevine exposure to diseases such as downy mildew by integrating precipitation in its definition, whereas the Branas Heliothermal Index (Branas 1974) and the Huglin Heliothermal Index (HI; Huglin 1978) include a day-length factor as a proxy for radiation. More complex indices, such as the Dryness Index (DI; Tonietto \& Carbonneau 2004), based on the potential water balance of the Riou Index (Riou et al. 1994), were developed in order to account for the soil-water availability at the beginning of the growing season (estimated as $200 \mathrm{~mm}$ ), for the potential evapotranspiration and for precipitation. By combining $\mathrm{HI}, \mathrm{CI}$ and DI, which are considered to be complementary indices, Tonietto \& Carbonneau (2004) have defined a Multicriteria Climatic Classification System (Geoviticulture MCC System) distinguishing 36 different climatic types. In this context, the bioclimatic indices are commonly used tools in viticultural zoning, as they allow the assessment of the potential suitability of a particular region for an economically sustained wine production.

The objectives of the present study are 3-fold: (1) to define the spatial patterns of a set of appropriate bioclimatic indices for a recent-past period (1960-2000) and for 3 future periods in the 21st century, consider- 
ing regional climate model datasets; (2) to differentiate viticultural climatic regions with diverse grape-growing suitability; and (3) to identify potential future geographical shifts in these regions, by analyzing significant changes in the index patterns. In terms of climatic viticultural zoning, only changes on climatological parameters are taken into account, leaving out other factors, such as possible changes on crop responses due to elevated carbon dioxide concentrations.

\section{MATERIALS AND METHODS}

A total of 7 bioclimatic indices (Table 1) were selected to analyse the impact of the projected future climatic changes on the European viticultural geography:

(1) Length of the growing season (LGS), calculated as the number of days with mean temperatures above $10^{\circ} \mathrm{C}$ (growing degree-days). Although depending on the different varieties, a region is commonly considered appropriate for vine growing for LGS higher than 182 d (Jackson 2001);

(2) Growing season precipitation (GSP; April to September), which was found to be one of the most discriminating climatic variables in northwestern Spain for current conditions (Blanco-Ward et al. 2007);

(3) Huglin Heliothermal Index (HI; Huglin 1978), which is a degree-day formulation that weights maximum temperatures above daily mean temperatures and applies a latitude-varying day-length adjustment. The day-length coefficient was linearly interpolated from 1.02 to 1.06 within the latitude belt 40 to $50^{\circ} \mathrm{N}$.
Southwards of $40^{\circ} \mathrm{N}$ the coefficient takes a value of 1.00 (Tonietto \& Carbonneau 2004). For latitudes 50 to $60^{\circ} \mathrm{N}$, a linear extrapolation was considered. HI is grouped into 6 climate classes, varying from very cool $(\mathrm{HI} \leq 1500)$ to very warm $(\mathrm{HI}>3000)$;

(4) Cool Night Index (CI), which provides a relative measure of ripening potential, being equal to the average minimum temperature during the month before harvest (September in the Northern Hemisphere) (Tonietto 1999). Four classes are differentiated: very cool nights $\left(\mathrm{CI} \leq 12^{\circ} \mathrm{C}\right)$, cool nights $\left(12<\mathrm{CI} \leq 14^{\circ} \mathrm{C}\right)$, temperate nights $\left(14<\mathrm{CI} \leq 18^{\circ} \mathrm{C}\right)$ and warm nights $(\mathrm{CI}$ $\left.>18^{\circ} \mathrm{C}\right)$;

(5) Hydrothermic Index of Branas, Bernon and Levadoux (HyI; Branas et al. 1946), which considers both precipitation and temperature regimes for estimating the risk of downy mildew disease (Carbonneau 2003). This risk is considered low when HyI has values below $2500^{\circ} \mathrm{C} \times \mathrm{mm}$ and high for values higher than $5100^{\circ} \mathrm{C} \mathrm{mm}$;

(6) Dryness Index (DI; Riou et al. 1994, Tonietto \& Carbonneau 2004), which defines 4 viticulture climates ranging from very dry (DI $\leq-100 \mathrm{~mm}$ ) to humid (DI > $150 \mathrm{~mm}$ ). It defines the soil-water component of the climate, assessing the level of dryness relevant for wine production in a specific region. For DI computation, potential evapotranspiration was estimated according to Blaney \& Criddle (1950).

(7) Composite Index (CompI), which summarizes the main results obtained from the previous indices. It is computed for each year separately and ranges between 0 and 1 (binomial and dimensionless index) de-

Table 1. Bioclimatic indices, their equations and respective references. LGS: length of the growing season; GSP: growing season precipitation; HI: Huglin Heliothermal Index; CI: Cool Night Index; HyI: Hydrothermic Index; DI: Dryness Index; CompI: Composite Index; $T_{\max }, T_{\min }, T_{\text {avg }}$ : maximum, minimum and mean daily temperatures, respectively; $d$ : correction coefficient of the day length as a function of latitude (see 'Materials and methods' for details); $P$ : precipitation; Wo: initial useful soil-water reserve; TV: potential transpiration; Es: direct evaporation from the soil

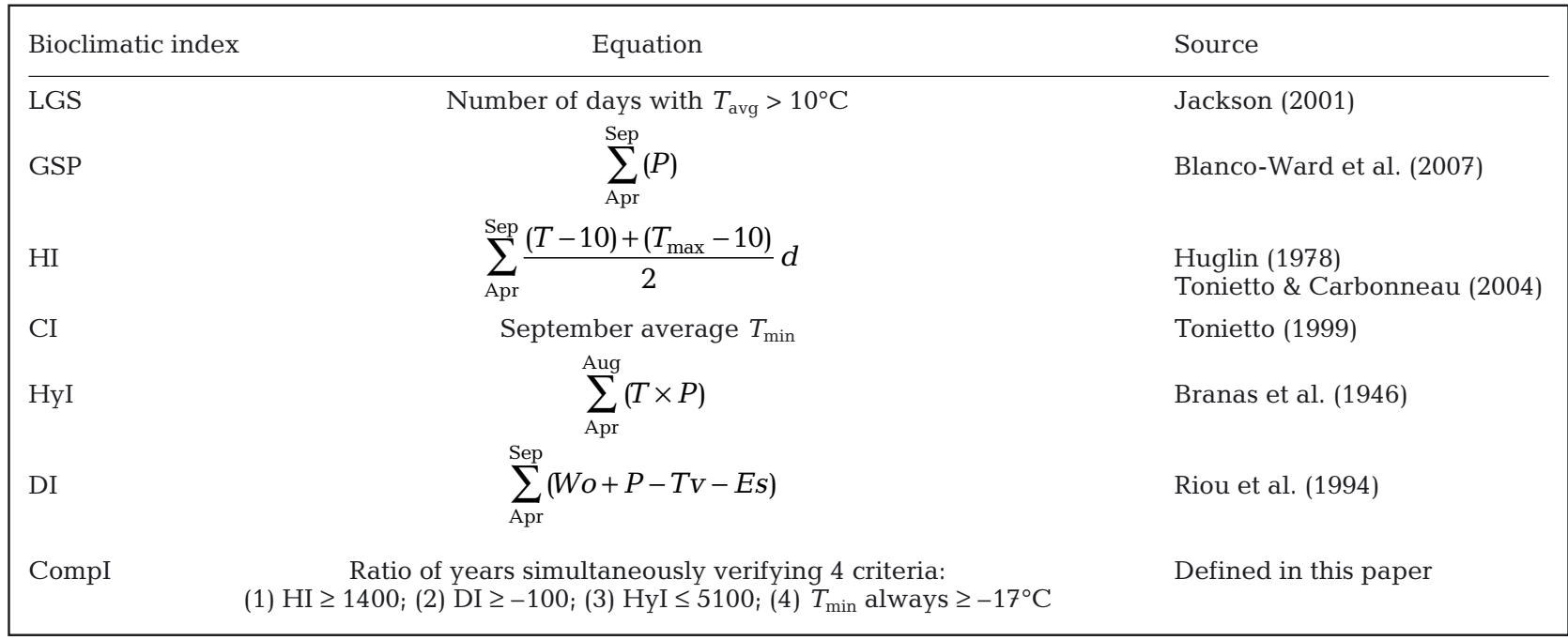


pending on whether the 4 conditions: $\mathrm{HI} \geq 1400$; DI $\geq$ -100 ; HyI $\leq 5100$ and daily minimum temperatures never below $-17^{\circ} \mathrm{C}$ are simultaneously accomplished. These thresholds are supported by literature (Branas et al. 1946, Huglin \& Schneider 1998, Tonietto and Carbonneau 2004). The $-17^{\circ} \mathrm{C}$ is considered the winterseverity constraint for vine survival (Hidalgo 2002).

The growing season period is considered to be from April to September in order to be consistent with the HI and DI definitions. The first 6 indices above provide valuable and complementary perspectives for climatic viticultural zoning in Europe. Additionally, the mean pattern of CompI gives the ratio of the winegrowing optimal years in a specific time period: a value of 0 means a total absence of suitable years within a time period of several decades, while a value of 1 means that all years are suitable for grapevine growing. For example, a value of 0.6 in a $30 \mathrm{yr}$ period indicates that $18 \mathrm{yr}$ are suitable. Following the same example, if the future projected changes are +0.3 (final value of 0.9 ), then $27 \mathrm{yr}$ out of 30 are suitable. Table 1 synthesizes the mathematical formulations of the indices and their corresponding references.

All bioclimatic indices are calculated using gridded atmospheric variables (daily precipitation amounts, daily mean air temperature, daily maximum and minimum temperatures), defined within a geographical sector covering most of Europe $\left(35^{\circ}\right.$ to $60^{\circ} \mathrm{N} ; 12^{\circ} \mathrm{W}$ to $\left.36^{\circ} \mathrm{E}\right)$ and simulated with the regional climate model COSMOCLM (Consortium for Small-Scale Modelling - Climate version of the Lokal-Model; Böhm et al. 2006, Rockel et al. 2008; hereafter CLM). Gridded model output is available with a spatial resolution of $0.165^{\circ}$ latitudelongitude (grid size of about $18 \mathrm{~km}$ ). As such, the indices are calculated using a high-resolution dataset in a large geographical sector and are defined on a daily basis.

A 2-member ensemble simulation of the recent-past climate (1960-2000; Lautenschlager et al. 2009a,b) and of the 21st century (Lautenschlager et al. 2009c-f) under the IPCC-SRES B1 and A1B scenarios are chosen; unfortunately, no comparable CLM simulations with the A2 scenario are available. These 2 forcing scenarios represent a relatively wide range of future greenhouse gas concentrations, which are related to remarkably different storylines of human development and population growth. The A1B scenario corresponds to a balance across all energy sources (fossil and nonfossil energies), while the B1 scenario features a more environmentally sustainable world (Nakiçenoviç et al. 2000); during the 21st century, the carbon dioxide concentration raises from $367 \mathrm{ppm}$ (year 2000) to $540 \mathrm{ppm}$ (B1) and $703 \mathrm{ppm}$ (A1B). All simulations were forced by ECHAM5/MPI-OM1 boundary conditions (Roeckner et al. 2006). Previous validation studies emphasize the skillfulness of CLM in reproducing different atmospheric fields for recent climate conditions (Hollweg et al. 2008). In this manner, CLM can be used in climate change assessment studies with confidence. An extensive evaluation of the climate change signal in these CLM simulations is presented in Hollweg et al. (2008), so it is not replicated here. Instead, the focus of this study is directly on the bioclimatic indices.

The patterns of the different bioclimatic indices were first computed for each year and for each ensemble member separately. However, for the sake of succinctness, only their ensemble mean patterns over specific periods are presented. The mean patterns for the recent-past period (1960-2000; C20 hereafter) are considered representative of current climatic conditions, while changes in these patterns for 3 selected future periods (2011-2040; 2041-2070 and 2071-2100) are a response of bioclimatic indices to human-driven climate change. Further, as each index pattern presents a large amount of information and detail (42126 grid points), the present study focuses primarily on the most relevant changes in terms of regional patterns. More detailed and in depth analysis for individual winegrowing areas are left for upcoming analyses.

\section{RESULTS}

The selected 7 bioclimatic indices are used to assess winegrape suitability across Europe under future climate conditions (see Figs. 1 to 7). The mean patterns for LGS and GSP in C20 and for the 3 future time periods under the A1B scenario are displayed in Fig. 1. The LGS and GSP patterns for C20 highlight the reliability of CLM in simulating the temperature and precipitation fields throughout Europe (Hollweg et al. 2008). A region is considered unsuitable for vine growing if the LGS is lower than $182 \mathrm{~d}$ (Jackson 2001), which roughly corresponds to regions northward of $52^{\circ} \mathrm{N}$ for current climate conditions (Fig. 1). In 2041-2070 and under the A1B scenario, this northern limit of wine production suitability is likely to undergo a northward displacement to $55^{\circ} \mathrm{N}$, with obvious exceptions over mountainous areas, such as the Alps. Results for the B1 emission scenario are rather consistent with those for A1B, though its changes are less significant (not shown). Hence, the projected climate change over Europe is expected to have a positive thermal effect on grapevine growing over most of Europe, with the clearest exception of high-latitude or high-altitude regions, where thermal conditions will remain far below the minimum climatic demands for an adequate vegetative development. With respect to the GSP, its fields depict decreases over most of Europe (Fig. 1), which is also in clear agreement with previous results obtained for the 

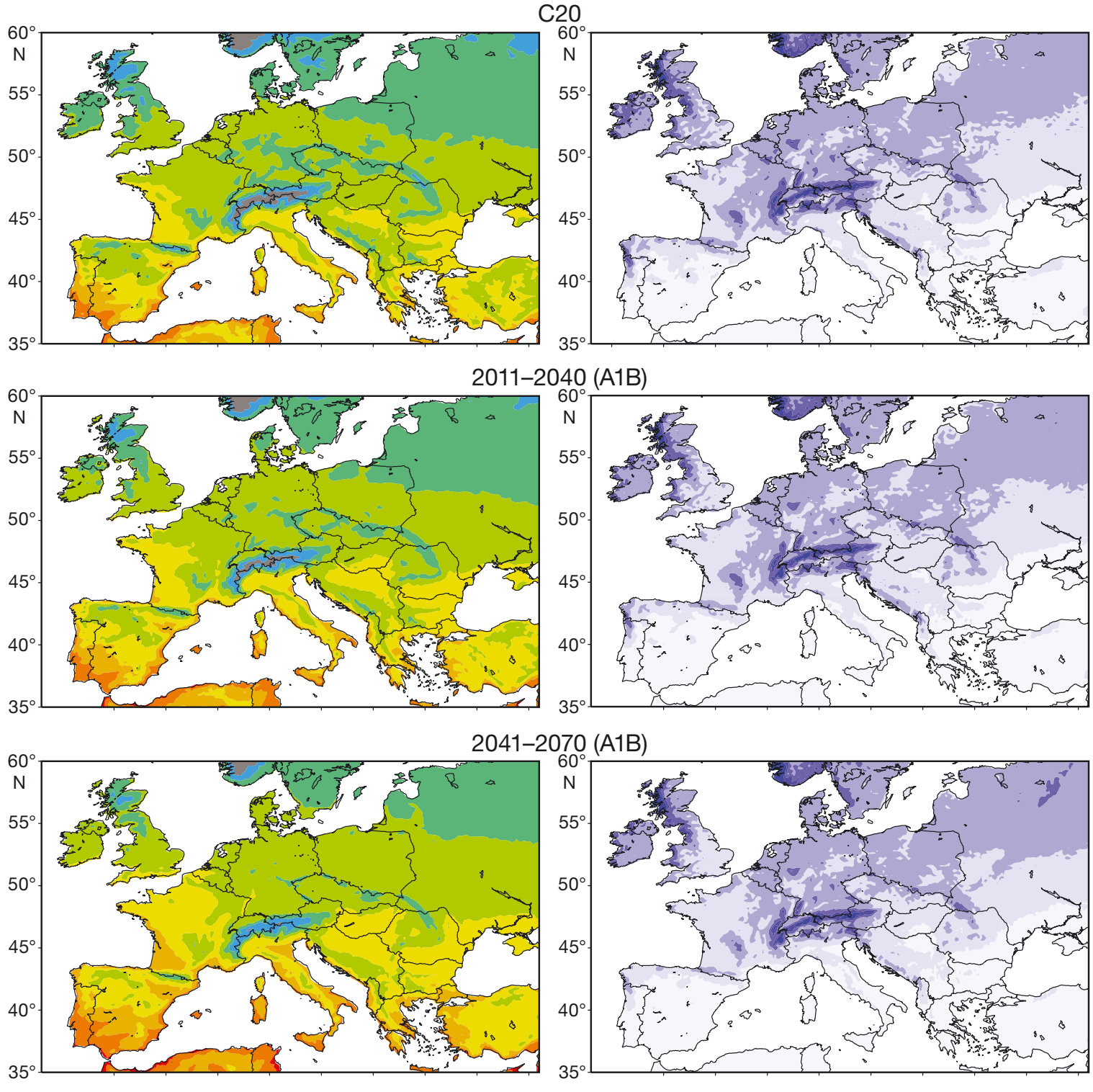

$2070(\mathrm{~A} 1 \mathrm{~B})$
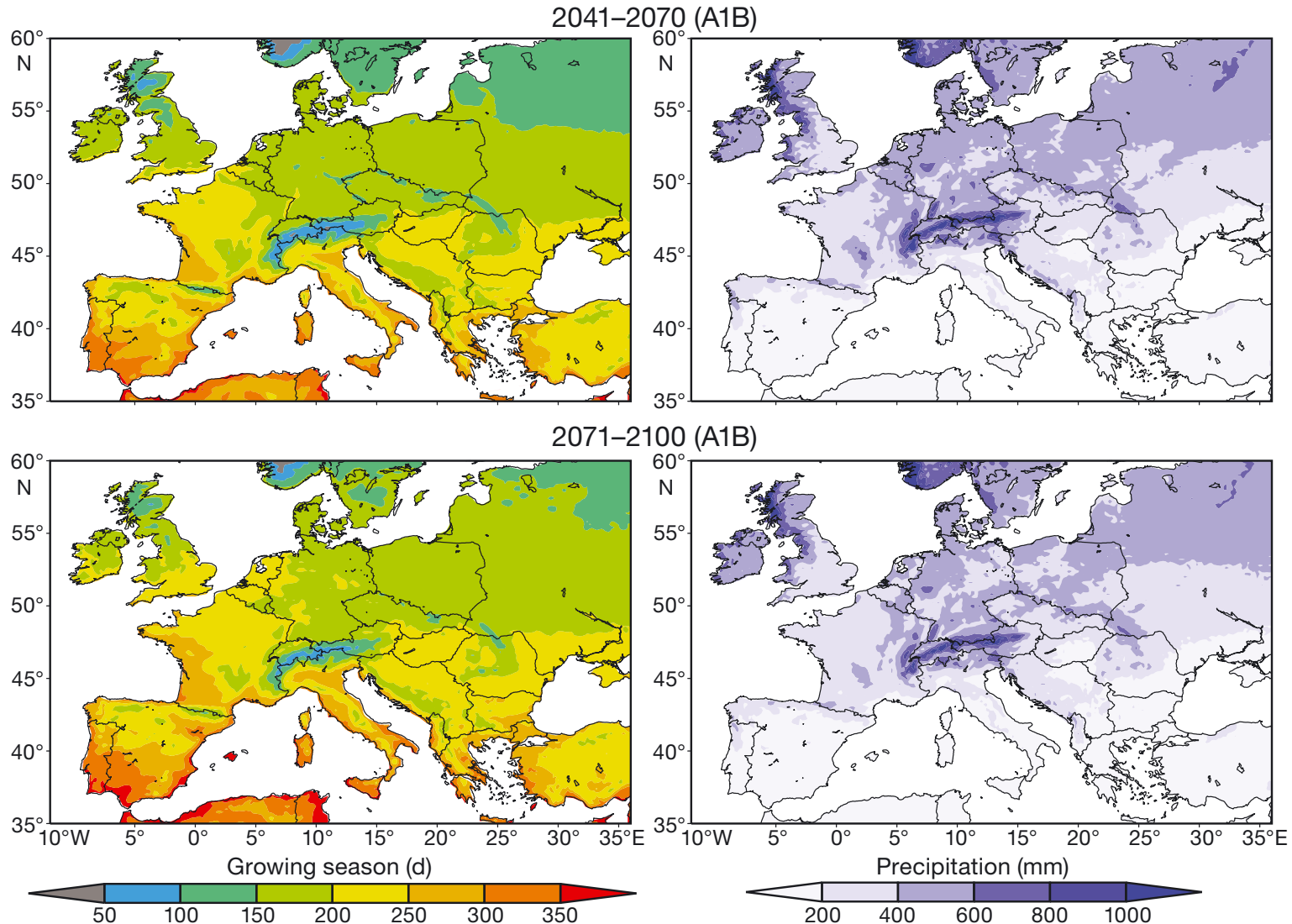

Fig. 1. On the left: Length of the growing season (number of days in a year with daily mean air temperature above $10^{\circ} \mathrm{C}$ ) for the outlined time periods. On the right: mean precipitation totals accumulated during the growing season (April to September) for the recent-past period (1960-2000; C20) and for 3 future periods under the A1B SRES emission scenario (2011-2040, 2041- 
summer half-year (e.g. Meehl et al. 2007). These changes in both temperature and precipitation fields will have an impact on the other bioclimatic indices, as will be shown below.

The HI has the advantage of integrating day-length and temperature (Huglin 1978), both variables that have a strong influence on grape development and quality (Spellman 1999, Jones \& Davis 2000, Hidalgo 2002). In fact, the relatively long day-lengths at high latitudes (high insolation) during the growing period lead to a northward extension of the viticultural zoning by partially compensating for lower temperatures. High values of HI reveal suitable areas for grapevines with late maturation, while low values are appropriate for early maturing varieties. As an illustration, Jones et al. (2005a) found a high positive correlation between $\mathrm{HI}$ and later season phenological events (véraison and harvest). Moreover, HI provides a better assessment of sugar potential of a vine variety than standard degreeday approaches such as the Winkler Index (Carbonneau 2003), despite both being highly correlated (Tonietto \& Carbonneau 2004, Blanco-Ward et al. 2007).

The HI mean pattern for C20 is generally in agreement with the LGS results (Fig. 2). This index shows that climatic conditions over northern Europe are not suitable for warmer climate varieties $(\mathrm{HI}<1500)$, neither for current conditions nor for future scenarios. On the other hand, it reveals viability in southern Europe, with generally high values, and in several areas of northern and central France and southwestern Germany, which are indeed renowned wine-producing areas. Although the HI mean pattern is reasonably coherent with the locations of some of the main European wine-producing regions (Clarke 1995), our results document the limitations of CLM in exactly reproducing the observed temperature fields and thus to fully capture all the details of the viticultural suitability in Europe. This fact can be largely attributed to its relatively coarse spatial resolution, to its smooth topography and to the inherent model bias. Nonetheless, the HI pattern reveals a strong similarity with patterns obtained using observational data (e.g. Stock et al. 2005), with only minor changes in detail. During the 21st century and under A1B, a significant northward extension of the regions with wine-producing potential is projected to occur, being particularly meaningful over large areas of southern England, Belgium, the Netherlands, Germany, the Czech Republic and southern Poland. Remarkably similar results were obtained for B1, but with much slower changes (Fig. 2); an approximate 30 yr delay can be detected relative to A1B. Analogous considerations can still be done for the other indices (see Fig. 3 to 6), though their mean patterns for B1 are displayed for a more comprehensive climate change assessment.
The CI mean pattern reveals that almost all of Europe presents very cool to temperate nights (average minimum temperatures in September lower than $18^{\circ} \mathrm{C}$ ), meaning that excessively warm nights in later maturity stages of grapes are relatively rare in Europe (Fig. 3). However, under both future scenarios, lowaltitude areas of the Mediterranean Basin are projected to undergo a significant increase in $\mathrm{CI}$, which might have potentially negative impacts on wine quality, as previously mentioned.

Variations in precipitation and thermal conditions (Fig. 1) may also have an important impact on moistureinduced diseases, such as downy mildew. The HyI mean pattern shows that areas with a Mediterraneantype climate tend to present low risks of contamination (first interval in the scale of Fig. 4), for both recent and future conditions, while higher latitudes generally present moderate to high risks, with an increasing trend over central and eastern Europe (second and third intervals in the scale of Fig. 4). This situation is particularly relevant for central Europe, where thermal conditions tend to become gradually favourable to wine production. Here, climate warming is accompanied by an insufficient decrease in precipitation, increasing or maintaining the risk of grapevine attack by the downy mildew pathogen. The risk of disease contamination can be a clear limitation to wine production and quality, in spite of the general improvement in thermal conditions. The projected precipitation decrease in southern Europe (Fig. 1) further decreases the pathogenic risk (Fig. 4), but this beneficial effect is largely offset by the negative effects of excessive dryness.

The DI pattern for recent climate conditions clearly highlights that moderate dry to very dry conditions prevail in southern Europe (lower 2 intervals in the scale of Fig. 5), while over higher latitudes sub-humid and humid conditions prevail (upper 3 intervals in the scale of Fig. 5). Moderately dry conditions are considered the most favourable for the production of highquality wines (Tonietto \& Carbonneau 2004), which is a clear advantage of southern Europe over higher latitudes. Nonetheless, excessive dryness (DI <-100 mm; first interval in Fig. 5) commonly leads to a state of hydrological stress in grapevines, having a potentially negative impact on wine yield and quality. Under the B1 and A1B scenarios, dryness is expected to increase over most of Europe. Some parts of southern Europe are effectively projected to become very dry (e.g. southern Iberia, Italy and southeastern Balkan Peninsula), so that irrigation of vineyards might be necessary to maintain wine yield and quality at current levels.

Aiming at quantifying the climatic suitability of a particular region for wine production, CompI provides the fraction of winegrowing optimal years (i.e. when the 4 conditions stated in the 'Materials and methods' are 
C20
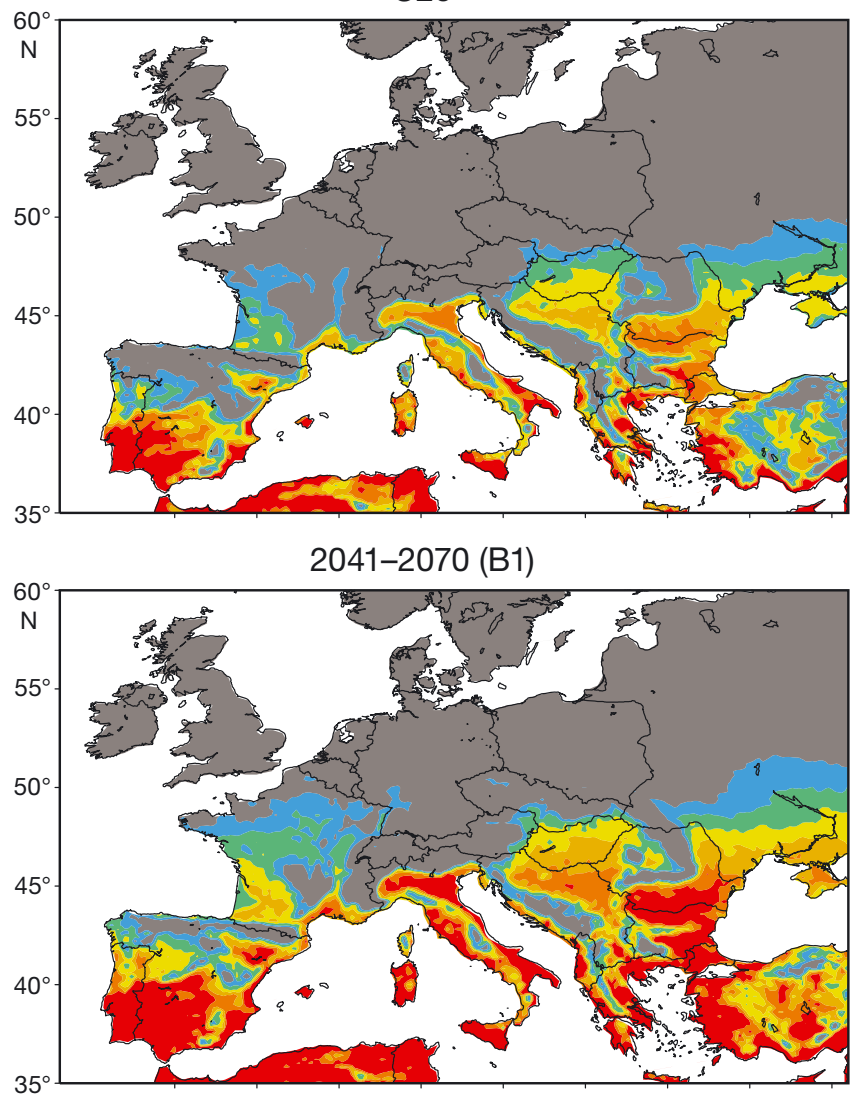

$2071-2100$ (B1)

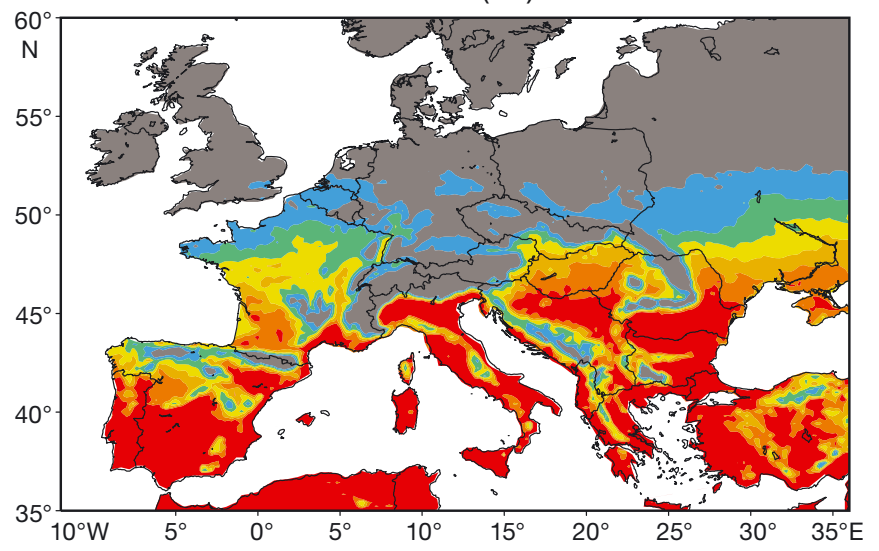

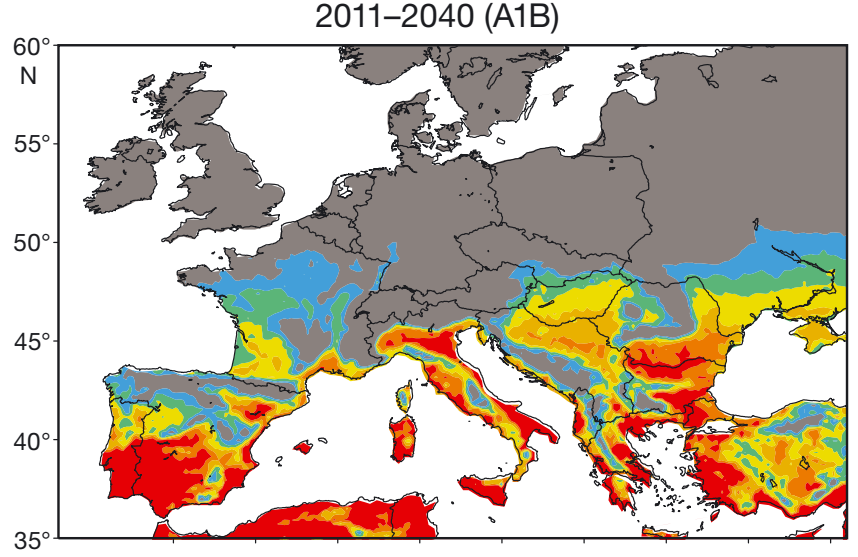

2041-2070 (A1B)

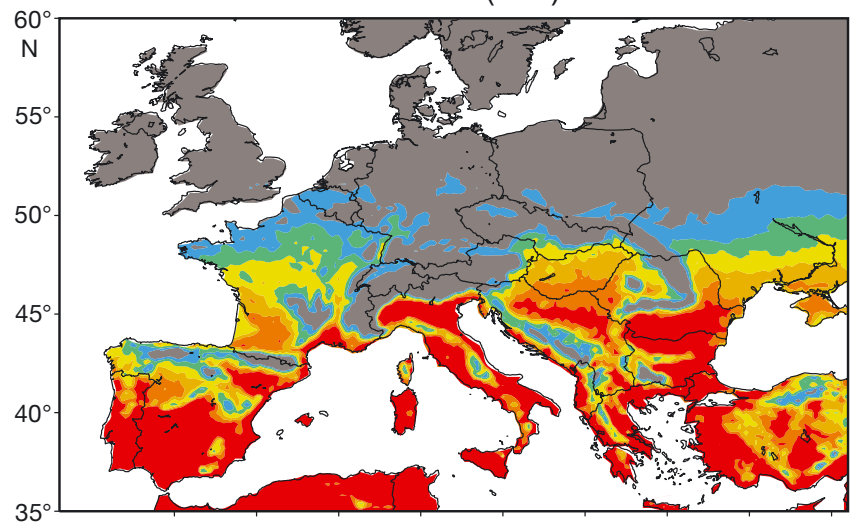

$2071-2100(\mathrm{~A} 1 \mathrm{~B})$

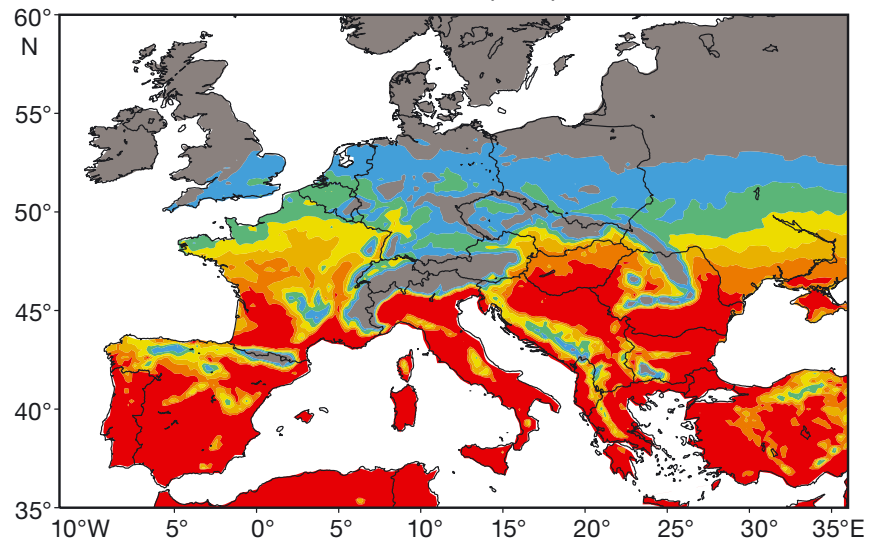

\section{\begin{tabular}{cc|cc|ccc|c}
\multicolumn{8}{c}{ Huglin heliothermal index $\left({ }^{\circ} \mathrm{C}\right)$} \\
\hline 1500 & 1800 & 2100 & 2400 & 2700 & 3000
\end{tabular}}

Fig. 2. Composites of the Huglin Heliothermal Index for the recent-past period (1960-2000; C20) and for 3 future periods under the B1 and A1B SRES emission scenarios (2011-2040, 2041-2070, 2071-2100). The pattern for 2011-2040 under the B1 scenario is not depicted as it is largely similar to the corresponding pattern for the A1B scenario. Classes were considered according to Huglin (1978)

simultaneously verified) in a certain time period and for each grid point in Europe (Fig. 6). The CompI mean pattern for C20 is mostly coherent with the spatial distribution of the viticultural areas in Europe (Fig. 6), attesting its usefulness in viticultural climatic zoning. In both scenarios, there is a clear northward extension of its pattern, which is particularly clear over several western European regions, especially in France. There are also some emerging wine-producing regions over central Europe, equatorward of $53^{\circ} \mathrm{N}$, in regions where temperatures can reach adequate values for grapevine development. Nevertheless, the warming will be com- 

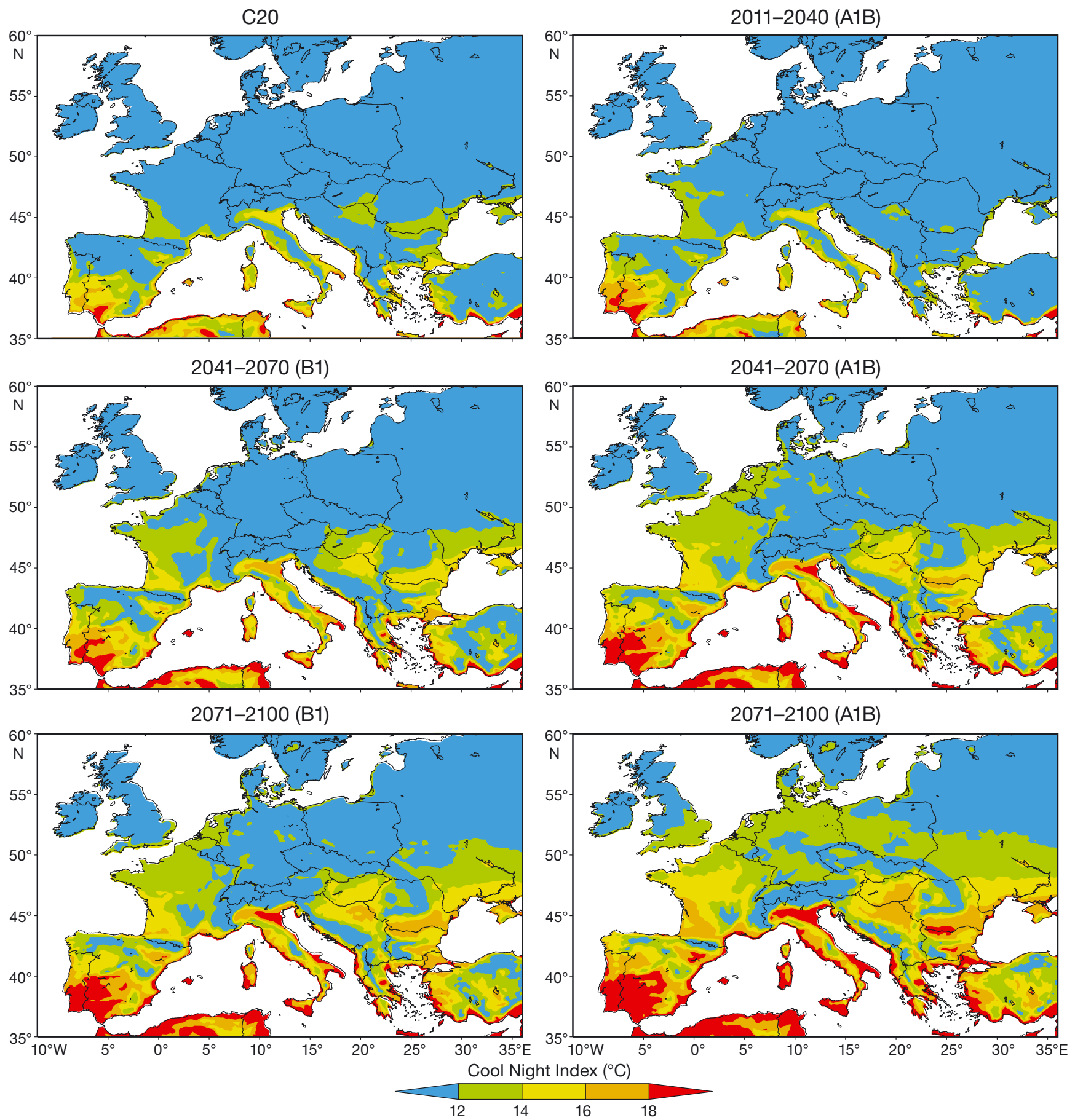

Fig. 3. As in Fig. 2, but for the Cool Night Index. Classes were considered according to Tonietto (1999)

bined with persistent humid conditions in most of central Europe (despite the precipitation decrease), which can present a serious threat to wine production, as the risk of grapevine contamination by diseases is very likely to maintain relatively high in the future (Fig. 4). In fact, if the HyI is excluded from CompI, an increase of about 0.1 to 0.2 (increase of 10 to $20 \%$ in the number of optimal years) is verified over central and eastern Europe (not shown). Conversely, the projected increase in dryness might have a strong negative impact on wine production and quality in some parts of southern Europe (DI below $-100 \mathrm{~mm}$ ), particularly in latitudes southward of $40^{\circ} \mathrm{N}$ (e.g. south-western Iberia), where sharp decreases in the CompI are depicted (Fig. 7). 

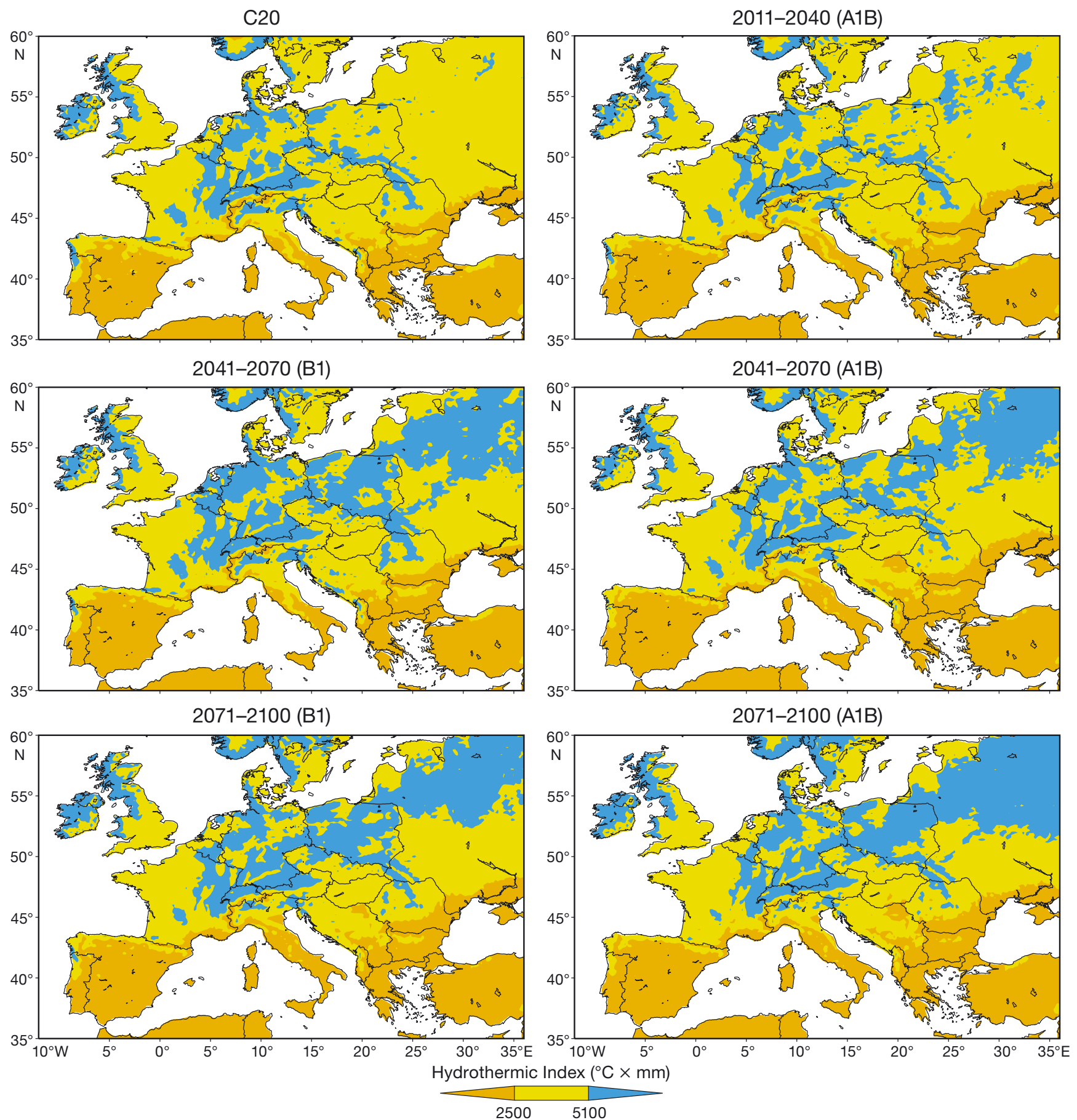

Fig. 4. As in Fig. 2, but for the Hydrothermic Index of Branas, Bernon and Levadoux. Classes were considered according to Branas et al. (1946)

In order to have a different perspective of the climate projections, the differences in the CompI mean patterns between each future period for A1B and C20 are shown in Fig. 7 ; the corresponding patterns for B1 were omitted as they do not present substantially different information from the A1B scenario (not shown). Results document progressive changes as the greenhouse gas forcing gradually increases, though there is also strong spatial heterogeneity. Focussing on the main feature, a prominent increase in the number of winegrowing optimal years is identified within the approximate latitude belt of 45 to $55^{\circ} \mathrm{N}$. In contrast, there is a significant decrease in the number of winegrowing optimal years over most of low- 

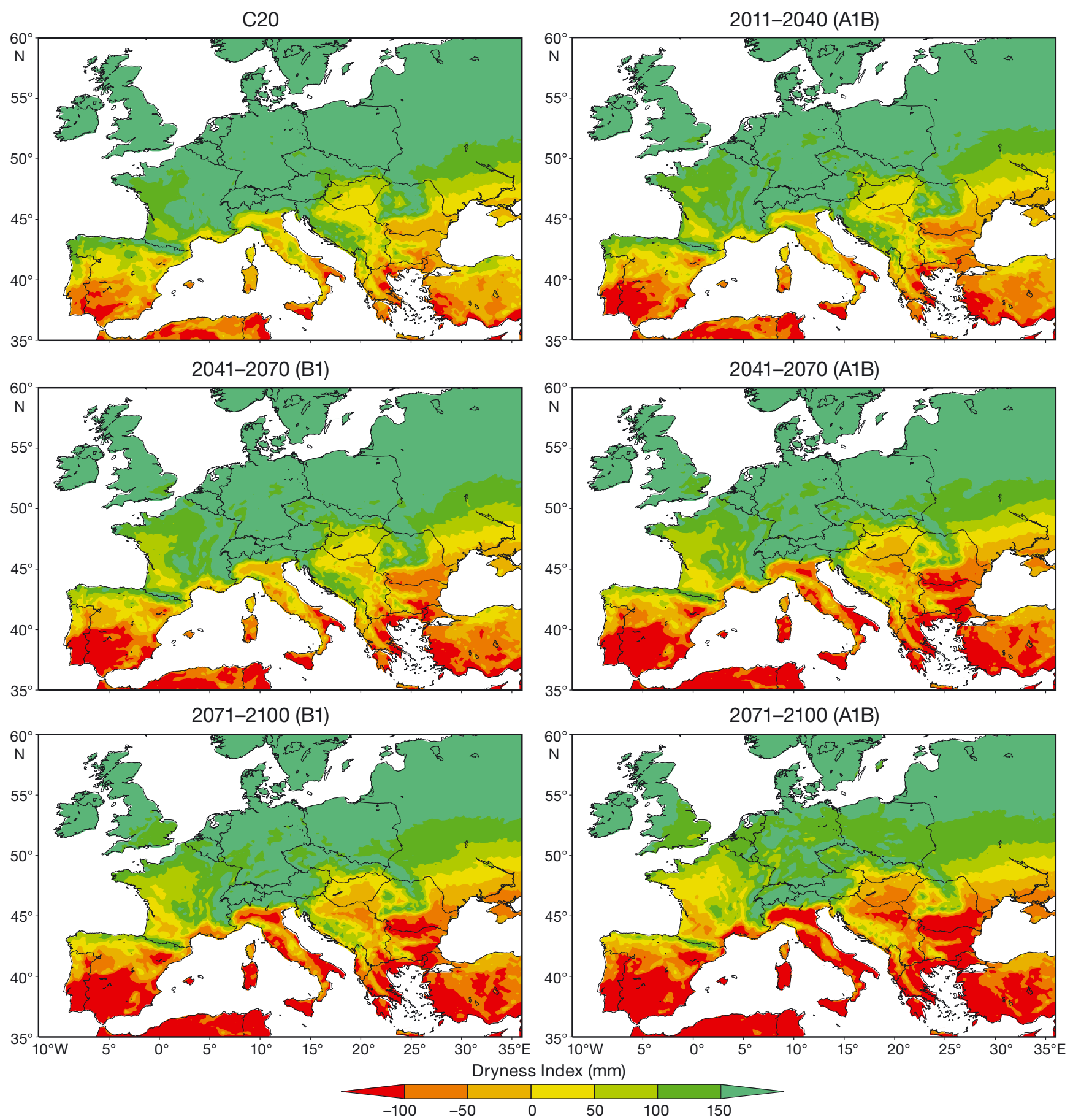

Fig. 5. As in Fig. 2, but for the Dryness Index. Classes were considered according to Tonietto \& Carbonneau (2004)

altitude areas in southern Europe, which is strictly due to the non-fulfillment of the DI $\geq-100 \mathrm{~mm}$ criterion. However, in southern European high-altitude regions the number of optimal years generally increase, and climatic factors in some mountainous areas are projected to be much more suitable for wine production than at present.

\section{DISCUSSION AND CONCLUSIONS}

Seven viticultural zoning indices show considerable changes in Europe in future decades. A reshaping of the European viticultural zoning is projected to occur mainly in the stronger scenario (A1B). Detrimental impacts on grapevine growth and development and on 

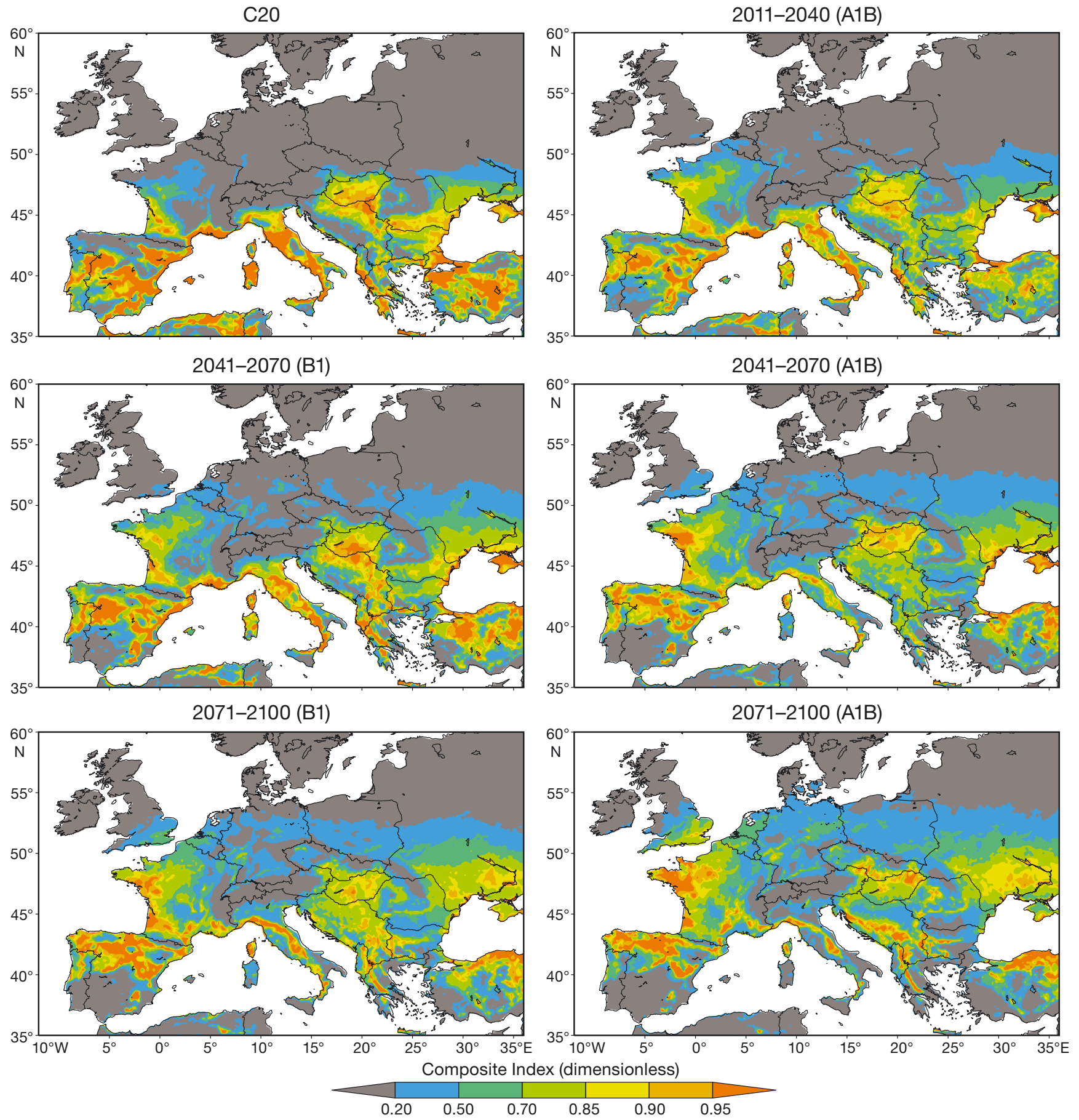

Fig. 6. As in Fig. 2, but for the Composite Index. The index values correspond to the fraction of years within the considered time period that are suitable for winegrape growing (see 'Material and methods' for details)

resulting wine yield and quality parameters are projected for southern Europe (e.g. Portugal, Spain and Italy) due to the increased cumulative thermal and dryness effects during the growing season. Conversely, western and central European regions (e.g. southern Britain, northern France and Germany) might benefit from future climate conditions through higher wine quality and new potential areas for viticulture. This general assessment is also supported by previous findings (e.g. Kenny \& Harrison 1992, Jones et al. 2005b, Stock et al. 2005).

The LGS is expected to rise all across Europe (Fig. 1), with several new potential viticultural areas in western and central Europe, featuring LGS values greater than 

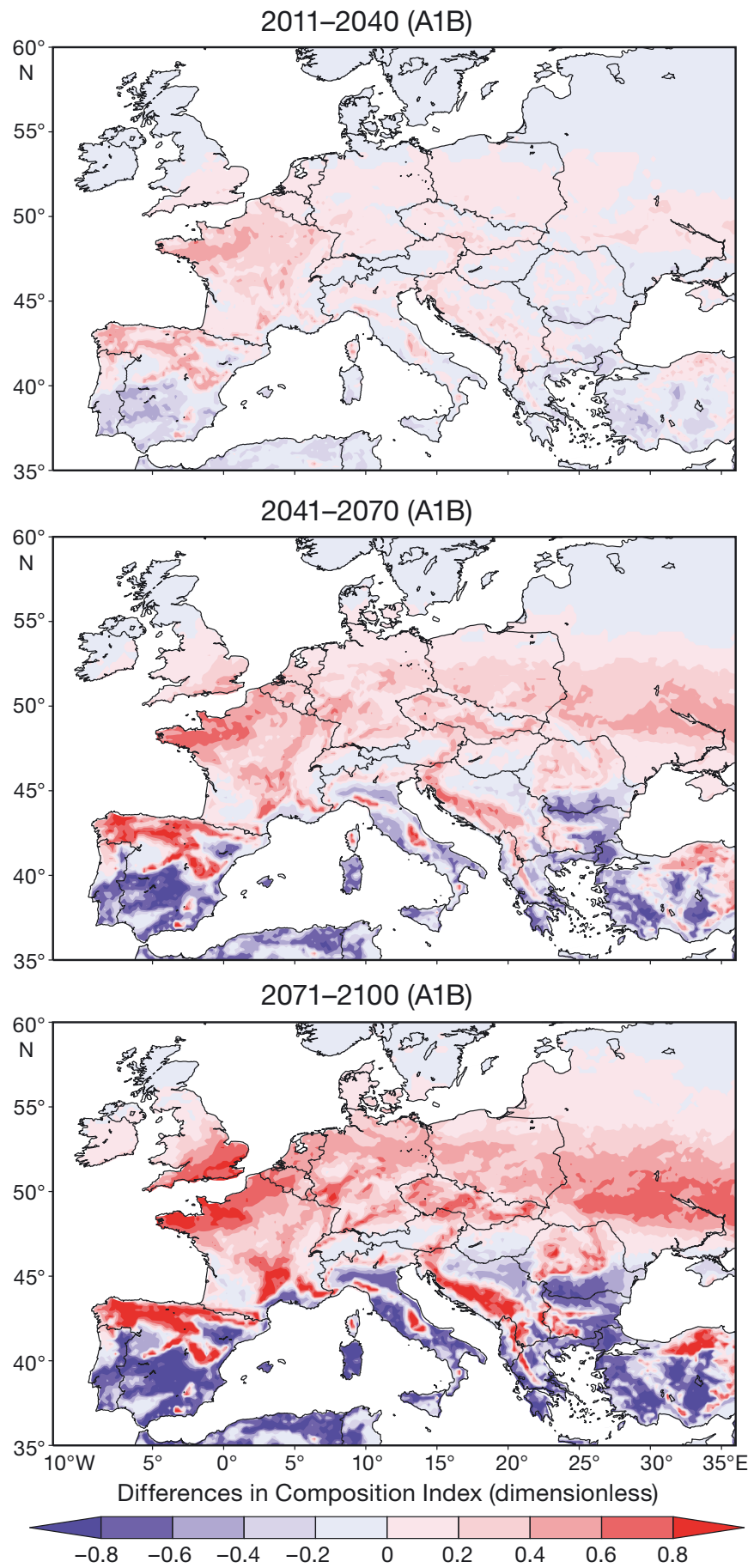

Fig. 7. Composite Index patterns of Fig. 6 (A1B scenario only) subtracted by the corresponding recent-past patterns (1960-2000; C20)

the commonly accepted minimum threshold (182 d; Jackson 2001). These results are consistent with recentpast trends for Alsace, France (Duchêne \& Schneider 2005) or with trends for other crops in Europe during the 20th century (Lough et al. 1983). Results presented here open the possibility for extending grapevine

growth to European regions currently too cold for this crop. Although GSP is predicted to decrease in most of Europe (Fig. 1), this is only of particular significance for southern Europe, where current precipitations are already low and, in some cases, at the lower limit for nonirrigated grapevine growth (Fig. 5). There is also a projected decrease in GSP over central and western Europe, but the total values remain high enough for winegrowing feasibility.

An increase of about 300 units in HI over the last 30 to $50 \mathrm{yr}$ in 6 European winegrowing regions was previously reported (Jones et al. 2005a). Similar trends were found in northeast Spain (Ramos et al. 2008), eastern France (Duchêne \& Schneider 2005) and central Italy (Orlandini et al. 2009). Using a statistical regional climate model and the A1B scenario, Stock et al. (2005) found that $\mathrm{HI}$ increased by 100 to 600 units in the years from 1951 to 2050, with lower values for some Mediterranean regions. In fact, excessive warming leads to significant changes in $\mathrm{HI}$, which is clear in the B1 and A1B scenarios presented here (Fig. 2); a northward extension of the mean HI pattern is clearly depicted in the future, with favourable values for grapevine growth projected in several areas of central and western Europe. CI establishes an equatorward limit for wine production, taking into account optimal temperatures for berry colour and terpenic aroma intensity during ripening (Tonietto \& Carbonneau 1998). Therefore, the projected CI enhancement in the future can have negative impacts on wine quality parameters in the Mediterranean (Fig. 3). Hence, the HI cannot express all thermal variability, as variability in nocturnal temperatures is also important to grape maturation, justifying the inclusion of $\mathrm{CI}$ in the thermal characterization of a region.

Despite the relevance of the previous results, precipitation and temperature changes can expose grapevines to plant pathogens and then limiting viticulture activities. The HyI patterns show that all areas with a Mediterranean-type climate in southern Europe present low risks of contamination, both in present and in future scenarios, whilst higher latitudes present moderate to high risks, with increasing values over central and eastern Europe (Fig. 4). This situation is particularly relevant for central Europe, where thermal conditions tend to be gradually favourable to wine production. In these regions, climate warming is not accompanied by a beneficial decrease in the risk of this epidemic. This can be a limitation to wine production, in spite of the general improvement in thermal conditions. For instance, a strengthening in this disease pressure (with resulting increase in fungicide sprays) was previously reported for a region in northwestern Italy under the A2 scenario, mostly because the effect of temperature increase overcomes the beneficial pre- 
cipitation decrease (Salinari et al. 2006). Nonetheless, the expected enhanced dryness (Fig. 5) and its associated severe water stress is also damaging for grapevine growth (Ojeda et al. 2001, Gu et al. 2004), albeit grape quality is favoured by mild water stress conditions during berry ripening (Koundouras et al. 1999, dos Santos et al. 2003).

The CompI patterns combine 4 well-established criteria for defining a winegrowing optimal year (Figs. 6 \& 7). Changes in its mean patterns reveal that in large areas of central and western Europe climatic factors are projected to become more suitable for grapevine growing, while in most of low-altitude regions in southern Europe (where traditional and highly renowned wine production sectors are located) grapevine growth is expected to face excessive dryness. However, higheraltitude areas in southern Europe can provide optimal alternatives for the viticultural sector, as thermal conditions might become mostly favourable and precipitation and humidity will remain above the minimum critical values. With respect to the current renowned viticultural areas in Europe, regions in central and western Europe (e.g. Bordeaux, Loire Valley, Bourgogne, Champagne, Alsace, Mosel, Rheingau, Mittelrhein) can be favoured, whereas regions in southern Europe (e.g. Alentejo, Douro Valley, Andalusia, Castile La-Mancha, Sicily, Puglia, Campania) can be negatively affected by climatic change. In addition, northernmost regions can gain potential for a wide range of wine varieties. In fact, a shift from white to red (more heat demanding) varieties is already happening in some German winegrowing regions (Stock et al. 2005).

These predicted changes are new challenges that can be a threat for the viticultural sector if no suitable adaptation measures are planned and implemented in a timely manner. For example, it will be necessary to implement vineyard irrigation in some excessively hot and dry climates, which might be the case for most of southern Europe at the end of the 21st century (Schultz 2000). Other studies also suggest that some southern European regions can become excessively warm and dry for producing high-quality wines (Kenny \& Harrison 1992, Jones et al. 2005b). However, the widespread implementation of irrigation systems can be expensive and environmentally unsustainable. Moreover, the predicted general rise in evaporation and the decrease in the amount of rainfall may limit such approaches on a wide scale. Furthermore, the fragile balance between agricultural water demands and increasing civil needs may raise political and legal issues. In northern Europe, adaptation measures are also required to take maximum advantage of the new favourable climatic conditions.

The present study is only focused on the climatic forcing on viticultural zoning in Europe. These climatic scenarios encompass some uncertainties related to the emission scenarios and to the model parameterizations and integrations. The direct effects of enhanced carbon dioxide concentration are out of the scope of the present study, though there is some evidence for positive physiological effects on grapevines (e.g. Moutinho-Pereira et al. 2009). Nevertheless, as this concentration will vary uniformly over the Earth's surface, it is not a direct differentiating factor among the European regions. Further, mesoclimate characteristics, local and egional orography and solar exposition are also important factors to consider as adaptation measures. Since new winegrowing regions might emerge in the future, their soil characteristics (e.g. morphology, texture, organic matter, soil depths) must not be ignored. Agricultural practices, wine production techniques, variety selection and genetic manipulation might also play a key role for the adaptation measures of the viticultural sector in response to climate change.

In future work, other emission scenarios will also be taken into account, such as the A2 SRES scenario (not currently available in the CLM dataset), which will provide a broader range of projected future conditions. The A2 scenario can be considered particularly realistic, since the current greenhouse gas emissions are already following its trajectory. Furthermore, the simulation of the climatic variables (e.g. temperature and precipitation fields) must be improved to correct existing bias. Since these model deficiencies explain some differences found between the simulated and the observed bioclimatic index patterns, their correction will increase the reliability of future projections.

Acknowledgements. Part of this study was supported by the project SUVIDUR -Sustentabilidade da Viticultura de Encosta nas Regiões do Douro e do Duero. Programa Operacional de Cooperação Transfronteiriça Espanha-Portugal (POCTEP). We thank the MPI for Meteorology (Hamburg, Germany), the German Federal Environment Agency, the WDCC/CERA database and the COSMO-CLM consortium for providing the COSMO-CLM data.

\section{LITERATURE CITED}

Amerine MA, Winkler AJ (1944) Composition and quality of musts and wines of California grapes. Hilgardia 15:493-675

Bates TR, Dunst RM, Joy P (2002) Seasonal dry matter, starch, and nutrient distribution in 'Concord' grapevine roots. HortScience 37:313-316

Berry J, Björkman O (1980) Photosynthetic response and adaptation to temperature in higher plants. Annu Rev Plant Physiol 31:491-543

Blanco-Ward D, Queijeiro JMG, Jones GV (2007) Spatial climate variability and viticulture in the Miño River Valley of Spain. Vitis 46:63-70

Blaney HF, Criddle WD (1950) Determining water requirements in irrigated areas from climatological and irrigation 
data. US Dept Agric, Soil Conservation Service, Tech Paper 96, Washington, DC

Böhm U, Kücken M, Ahrens W, Block A and others (2006) CLM -the climate version of LM: brief description and long-term applications. COSMO Newsl 6:225-235

Branas J (1974) Viticulture. Imp. Dehan, Montpellier

Branas J, Bernon G, Levadoux L (1946) Eléments de viticulture générale. Imp. Dehan, Montpellier

Carbonneau A (2003) Ecophysiologie de la vigne et terroir. In: Fregoni M, Schuster D, Paoletti A (eds) Terroir, zonazione, viticoltura. Trattato internazionale, Phytoline, Piacenza, p 61-102

Clarke O (1995) Oz Clarke's wine atlas. Wines and wine regions of the world. Little Brown \& Co, London

dos Santos TP, Lopes CM, Rodrigues ML, de Souza CR and others (2003) Partial rootzone drying: effects on growth and fruit quality of field grown grapevines (Vitis vinifera). Funct Plant Biol 30:663-671

Duchêne E, Schneider C (2005) Grapevine and climatic changes: a glance at the situation in Alsace. Agron Sustain Dev 25:93-99

Field SK, Smith JP, Holzapfel BP, Hardie W, Emery RJN (2009) Grapevine response to soil temperature: xylem cytokinins and carbohydrate reserve mobilization from budbreak to anthesis. Am J Enol Vitic 60:164-172

Fregoni M (2003) L'indice bioclimatico di qualità Fregoni. In: Fregoni M, Schuster D, Paoletti A (eds) Terroir, zonazione, viticoltura. Trattato internazionale, Phytoline, Piacenza, p 115-127

Gladstones J (1992) Viticulture and environment. Winetitles, Adelaide

Gu S, Du G, Zoldoske D, Hakim A, Cochran R, Fugelsang K, Jorgensen $G$ (2004) Effects of irrigation amount on water relations, vegetative growth, yield and fruit composition of Sauvignon blanc grapevines under partial rootzone drying and conventional irrigation in the San Joaquin Valley of California, USA. J Hortic Sci Biotechnol 79:26-33

Hidalgo L (2002) Tratado de viticultura general. Ediciones Mundi-Prensa, Madrid

Hollweg HD, Böhm U, Fast I, Hennemuth B and others (2008) Ensemble simulations over Europe with the regional climate model CLM forced with IPCC AR4 global scenarios. M \& D Technical Report 3. (available: www.mad.zmaw. de/service-support/documents/reports/)

Huglin P. (1978) Nouveau mode d'évaluation des possibilités héliothermiques d'un milieu viticole. CR Acad Agr 64: 1117-1126

Huglin P, Schneider C (1998) Biologie et écologie de la vigne. Lavoisier Tec et Doc, Paris

Jackson D (2001) Climate: monographs in cool climate viticulture-2. Daphne Brasell Associates, Wellington

Jones GV (2006) Climate and terroir: impacts of climate variability and change on wine. In: Macqueen RW, Meinert LD (eds) Fine wine and terroir - the geoscience perspective. Geoscience Canada Reprint Series Number 9, Geological Association of Canada, St. John's 247

Jones GV, Davis RE (2000) Climate influences on grapevine phenology, grape composition, and wine production and quality for Bordeaux, France. Am J Enol Vitic 51:249-261

Jones GV, Duchêne E, Tomasi D, Yuste J and others (2005a) Changes in European winegrape phenology and relationships with climate. In: Proceedings of the Groupe d'Etude des Systèmes de Conduite de la vigne (GESCO 2005). Gesellschaft zur Förderung der Forschungsanstalt, Geisenheim, p 1-6

Jones GV, White MA, Cooper OR, Storchmann K (2005b) Climate change and global wine quality. Clim Change 73:319-343
Kenny GJ, Harrison PA (1992) The effects of climate variability and change on grape suitability in Europe. J Wine Res 3:163-183

Kliewer WM (1977) Effect of high temperature during the bloom-set period on fruit-set, ovule fertility, and berry growth of several grape cultivars. Am J Enol Vitic 28: 215-222

Kliewer WM, Soleimani A (1972) Effect of chilling on budbreak in 'Thompson seedless' and 'Carignane' grapevines. Am J Enol Vitic 23:31-34

Kliewer WM, Torres RE (1972) Effect of controlled day and night temperatures on grape coloration. Am J Enol Vitic 23:71-77

Kottek M, Grieser J, Beck C, Rudolf B, Rubel F (2006) World map of the Köppen-Geiger climate classification updated. Meteorol Z (Berl) 15:259-263

Koundouras S, van Leeuwen C, Seguin G, Glories Y (1999) Influence de l'alimentation en eau sur la croissance de la vigne, la maturation des raisins et les caractéristiques des vins en zone méditerranéenne (exemple de Némée, Grèce, cépage Saint-Georges, 1997). J Int Sci Vigne Vin 33:149-160

Lautenschlager M, Keuler K, Wunram C, Keup-Thiel E and others (2009a) Climate Simulation with CLM, Climate of the 20th Century run no.1, data stream 3: European region MPI-M/MaD. World Data Center for Climate, doi:10.1594/ WDCC/CLM_C20_1_D3. www.regionaler-klimaatlas.de/ glossar/cosmo-clm.html

Lautenschlager M, Keuler K, Wunram C, Keup-Thiel E and others (2009b) Climate simulation with CLM, Climate of the 20th Century run no. 2, data stream 3: European region MPI-M/MaD. World Data Center for Climate, doi:10.1594/ WDCC/CLM_C20_2_D3. www.regionaler-klimaatlas.de/ glossar/cosmo-clm.html

Lautenschlager M, Keuler K, Wunram C, Keup-Thiel E and others (2009c) Climate simulation with CLM, scenario a1b run no. 1, data stream 3: European region MPI-M/MaD. World Data Center for Climate, doi:10.1594/WDCC/CLM_ A1B_1_D3. www.regionaler-klimaatlas.de/glossar/cosmoclm.html

Lautenschlager M, Keuler K, Wunram C, Keup-Thiel E and others (2009d) Climate simulation with CLM, scenario A1B run no. 2, data stream 3: European region MPI-M/MaD. World Data Center for Climate, doi:10.1594/WDCC/CLM_ A1B_2_D3. www.regionaler-klimaatlas.de/glossar/cosmoclm.html

Lautenschlager M, Keuler K, Wunram C, Keup-Thiel E and others (2009e) Climate simulation with CLM, scenario B1 run no. 1, data stream 3: European region MPI-M/MaD. World Data Center for Climate, doi10.1594/WDCC/CLM_B1_1_D3. www.regionaler-klimaatlas.de/glossar/cosmo-clm.html

Lautenschlager M, Keuler K, Wunram C, Keup-Thiel E and others (2009f) Climate simulation with CLM, scenario B1 run no. 2, data stream 3: European region MPI-M/MaD. World Data Center for Climate, doi:10.1594/WDCC/CLM_B1_2_D3. www.regionaler-klimaatlas.de/glossar/cosmo-clm.html

Lough JM, Wigley TML, Palutikof JP (1983) Climate and climate impact scenarios for Europe in a warmer world. J Clim Appl Meteorol 22:1673-1684

Magalhães NP (2008) Tratado de viticultura - a videira, a vinha e o 'terroir'. Chaves Ferreira Publicações, Lisboa

Meehl GA, Stocker TF, Collins WD, Friedlingstein AT and others (2007) Global climate projections. In: Solomon S et al. (eds) Climate change 2007: the physical science basis. Contribution of Working Group I to the Fourth Assessment Report of the Intergovernmental Panel on Climate Change. Cambridge University Press

Moutinho-Pereira J, Gonçalves B, Bacelar E, Cunha JB, 
Coutinho J, Correia CM (2009) Effects of elevated $\mathrm{CO}_{2}$ on grapevine (Vitis vinifera L.): physiological and yield attributes. Vitis 48:159-165

Mullins MG, Bouquet A, Williams LE (1992) Biology of the grapevine (Biology of horticultural crops). Cambridge University Press

Nakiçenoviç N, Alcarno J, Davis G, de Vries B and others (2000) Emissions scenarios. A special report of Working Group III of the Intergovernmental Panel on Climate Change. Cambridge University Press, Cambridge

Nemani RR, White MA, Cayan DR, Jones GV, Running SW, Coughlan JC, Peterson DL (2001) Asymmetric warming over coastal California and its impact on the premium wine industry. Clim Res 19:25-34

OIV (Organisation Internationale de la Vigne et du Vin) (2006) Situation and statistics of the world viticultural sector in 2006. www.oiv.int (accessed 18 May 2010)

Ojeda H, Deloire A, Carbonneau A (2001) Influence of water deficits on grape berry growth. Vitis 40:141-145

Orlandini S, Stefano V, Lucchesini P, Puglisi A, Bartolini G (2009) Current trends of agroclimatic indices applied to grapevine in Tuscany (Central Italy). Idöjárás 113:69-78

Ramos MC, Jones GV, Martínez-Casasnovas JA (2008) Structure and trends in climate parameters affecting winegrape production in northeast Spain. Clim Res 38:1-15

Riou C, Becker N, Sotés Ruiz V, Gomez-Miguel V and others (1994) Le déterminisme climatique de la maturation du raisin: application au zonage de la teneur en sucre dans la communauté européenne. Office des Publications Officielles des Communautés Européennes, Luxembourg

Rockel B, Will A, Hense A (2008) The regional climate model COSMO-CLM. Meteorol Z (Berl) 17:347-348

Roeckner E, Brokopf R, Esch M, Giorgetta M, Hagemann S, Kornblueh L (2006) Sensitivity of simulated climate to horizontal and vertical resolution in the ECHAM5 atmosphere model. J Climate 19:3771-3791

Salinari F, Giosuè S, Tubiello FN, Rettori A and others (2006) Downy mildew (Plasmopara viticola) epidemics on grape-

Editorial responsibility: Tim Sparks, Cambridge, UK vine under climate change. Glob Change Biol 12: 1299-1307

Santos JA, Malheiro AC, Karremann MK, Pinto JG (2010) Statistical modelling of grapevine yield in the Port Wine region under present and future climate conditions. Int $\mathrm{J}$ Biometeorol, doi:10.1007/s00484-010-0318-0

Schultz HR (2000) Climate change and viticulture: a European perspective on climatology, carbon dioxide and UV-B effects. Aust J Grape Wine Res 6:2-12

Spellman G (1999) Wine, weather and climate. Weather 54:230-239

Stock M, Gerstengarbe FW, Kartschall T, Werner PC (2005) Reliability of climate change impact assessments for viticulture. Proceedings of the VII International Symposium on Grapevine Physiology and Biotechnology. Acta Hortic 689:29-39

Tonietto J (1999) Les macroclimats viticoles mondiaux et l'influence du mésoclimat sur la typicité de la Syrah et du Muscat de Hambourg dans le sud de la France: méthodologie de caractérisation. PhD dissertation, Ecole Nationale Supérieure Agronomique, Montpellier

Tonietto J, Carbonneau A (1998) Facteurs mésoclimatiques de la typicité du raisin de table de l'A.O.C, Muscat du Ventoux dans le Département de Vaucluse. Prog Agric Vitic 12:271-279

Tonietto J, Carbonneau A (2004) A multicriteria climatic classification system for grape-growing regions worldwide. Agric Meteorol 124:81-97

van Leeuwen C, Friant P, Choné X, Tregoat O, Koundouras S, Dubourdieu D (2004) Influence of climate, soil, and cultivar on terroir. Am J Enol Vitic 55:207-217

> Vaudour E (2002) The quality of grapes and wine in relation to geography: notions of terroir at various scales. J Wine Res 13:117-141

Vaudour E, Shaw AB (2005) A worldwide perspective on viticultural zoning. S Afr J Enol Vitic 26:106-115

Winkler AJ, Cook JA, Kliwer WM, Lider LA (1974) General viticulture. University of California Press, Berkeley

Submitted: May 25, 2010; Accepted: August 4, 2010

Proofs received from author(s): September 17, 2010 